\title{
Genetic parameters in agronomic characters for selection of superior lineages of Ricinus communis $\mathbf{L}$
}

\section{Laurenice Araujo dos Santos ${ }^{* *}$ (iD) Simone Alves Silva ${ }^{1}$ Deoclides Ricardo de Souza ${ }^{2}$ Gilmara de Melo Araujo ${ }^{2}$ Vanessa de Oliveira Almeida ${ }^{3}$ (iD Cláudia Garcia Neves ${ }^{4}$}

\author{
${ }^{1 *}$ Center for Agrarian, Environmental and Biological Sciences, Universidade Federal do Recôncavo da Bahia (UFRB), Av. Rui Barbosa, 710, \\ 44380-000, Cruz das Almas, BA, Brasil. E-mail: lasagro@hotmail.com. "Corresponding author. \\ ${ }^{2}$ Universidade Federal do Recôncavo da Bahia (UFRB), Cruz das Almas, BA, Brasil. \\ ${ }^{3}$ Faculdade Maria Milza (FAMAM), Governador Mangabeira, BA, Brasil. \\ ${ }^{4}$ Universidade Estadual de Santa Cruz (UESC), Rodovia Ilhéus, Itabuna, BA, Brasil.
}

ABSTRACT: Knowledge on the variability and heritability of agronomic characters of interest aid the selection of superior materials. Thus, the objective of this study was to evaluate the genetic parameters of agronomic traits in castor bean plant lineages and to quantify the genetic correlations between them. The study was performed in the experimental area of the Federal University of the Reconcavo da Bahia, Cruz das Almas, Bahia. Seed oil content, vegetative cycle, plant height, and the number and weight of seeds per plant were evaluated in 47 lineages of castor bean seedlings. The coefficient of genetic variation was higher for weight of seeds per plant, revealing greater variability. The broadsense heritability of individual plots presented a higher value for oil content and a lower value for seed number per plant. Selection precision was moderate for plant height, number and weight of seeds per plant, high for vegetative cycle, and very high for oil content. The genetic parameters allowed superior genotypes to be ranked and selected. Positive correlations between vegetative cycle and plant height, associated with negative correlations for number and weight of seeds, and oil content, allow significant gains for crop productivity.

Key words: castor bean plant, genetic correlation, heritability, genetic improvement.

Parâmetros genéticos em caracteres agronômicos na seleção de linhagens superiores de Ricinus communis $\mathbf{L}$

RESUMO: $O$ conhecimento da variabilidade e herdabilidade dos caracteres agronômicos de interesse auxiliam na seleção de materiais superiores. Desta forma, objetivou-se avaliar os parâmetros genéticos de caracteres agronômicos em linhagens de mamoneira e quantificar as correlações genéticas entre eles. O trabalho foi desenvolvido na área experimental da Universidade Federal do Recôncavo da Bahia, Cruz das Almas, Bahia. Foram avaliados o teor de óleo na semente, ciclo vegetativo, estatura de planta, número de sementes por planta e peso de sementes por planta em 47 linhagens de mamoneira. O coeficiente de variação genético foi maior para o peso de sementes por planta revelando maior variabilidade. A herdabilidade de parcelas individuais no sentido amplo apresentou maior valor para o teor de óleo e menor valor para o número de sementes por planta. A precisão de seleção foi moderada para estatura de planta, número de sementes por planta e peso de semente por planta; alta para o ciclo vegetativo; e muito alta para o teor de óleo. Os parâmetros genéticos permitiram o ranqueamento e seleção dos genótipos superiores. As correlações positivas entre o ciclo vegetativo e estatura de planta, associada às correlações negativas para o número de sementes, peso de sementes e teor de óleo, possibilitam ganhos expressivos para a produtividade da cultura.

Palavras-chave: mamoneira, correlação genética, Herdabilidade, melhoramento genético.

\section{INTRODUCTION}

Castor bean plant (Ricinus communis L.) is cultivated in small and medium farms, and in large plantations. It is a non-edible oilseed plant with high oil production capacity, with more than 700 industrial uses, such as the manufacture of paints, varnishes, synthetic fibers, lubricants, solvents, nylon, hydraulic fluids, special greases, cosmetics, and prostheses, and is the only vegetable oil soluble in alcohol (COSTA et al., 2005; BAJAY et al., 2009; JEONG AND PARK, 2009; FALASCA et al., 2012).

To meet the growing need for seeds, genetic improvement of the crop and the creation of new genotypes is the most economical way to achieve the required increase in production of this oilseed (OLIVEIRA JUNIOR \& ZANOTTO, 2008; DAPKE et al., 2016; SALIHU et al., 2017). The great variability among castor bean genotypes means there is a large genetic base for the creation of new strains with favorable genetic combinations. Therefore, a substantial challenge for breeders is to aggregate the highest possible frequency of desirable alleles in a single genotype (SEVERINO et al., 2006; PASSOS et al., 2010; PATEL \& PATEL, 2014; SILVA et al., 2017).

Genetic improvement depends on the right choice of the best individuals to be the progenitors of the next generations. Thus, the evaluation of genetic parameters, such as coefficient of genetic variance and heritability, are important tools for 
genetic improvement, since they provide information on genetic variability, the degree of expression of a character between generations, and the possibility of gains through direct or indirect selection (ROCHA et al., 2003; PASSOS et al., 2010). Although, some studies investigating genetic parameters have been carried out on castor bean plants (OLIVEIRA \& ZANOTTO, 2008; PASSOS et al., 2010; DA SILVA et al., 2011; OLIVEIRA et al., 2013;), further studies are needed to obtain improved materials.

Estimation of genetic parameters through restricted maximum likelihood/best linear unbiased prediction (REML/BLUP) ensures greater precision and allows inferences to be made about the genetic effects of treatments, allowing a more accurate estimation of the genetic value and a more adequate ranking of the superior individuals, resulting in better selection. However, other models can be applied, especially those that aim for the joint analysis of several experiments (MARTINEZ et al., 2011).

Knowledge on the correlations between agronomic traits is important for genetic improvement studies, since they guide the selection of superior lineages, especially when the characters are favorably correlated, which makes it possible to obtain gains for one character indirectly by selection of an associated character. This is advantageous, especially when a character of high economic value has low heritability or is difficult to evaluate compared with another associated character (CRUZ et al., 1997; RODRIGUES et al., 2010). However, if a character is positively correlated with other characters and negatively correlated with others, it is important to take care to avoid selecting for a character that may cause some undesirable change.

In view of the above, the objective of this study was to evaluate the genetic parameters of agronomic characters in castor bean plant lineages and to quantify the genetic correlations between them.

\section{MATERIALS AND METHODS}

The experiment was carried out in two agricultural years, 2010 and 2011, in the experimental area of the Genetic Improvement and Biotechnology Nucleus (NBIO) of the Center for Agrarian, Environmental, and Biological Sciences of the Universidade Federal do Recôncavo da Bahia (CCAAB/UFRB), located in the municipality of Cruz das Almas - Bahia, in a randomized complete block design with four replicates.

The following characteristics were evaluated: seed oil content; vegetative cycle; plant height; and number and weight of seeds per plant in 47 lineages. The study population included individuals derived from selection at $21 \%$ selection pressure in a generation with high homozygosity, which was conducted by the single seed descent (SSD) method. The segregating population F2 was obtained by self-fertilization of the $\mathrm{F} 1$ population resulting from hybridization of the parents: BRS 149 Nordestina, BRS 188 Paraguaçu, EBDA MPA-17, Mirante 10, and Sipeal 28.

The area in which the experiment was installed was properly prepared by plowing and harrowing. After soil analysis, acidity was corrected and the planting hole was fertilized with a dose of $20 \mathrm{~kg} \mathrm{ha}^{-1}$ of $\mathrm{N}, 80 \mathrm{~kg} \mathrm{ha}^{-1}$ of $\mathrm{P}$, and $40 \mathrm{~kg} \mathrm{ha}^{-1}$ of $\mathrm{K}$. Commercial spacings of $\mathrm{m}$ between rows and $1 \mathrm{~m}$ between plants were used. Planting was performed by direct seeding in the field, using three seeds per hole. Approximately 30 days after planting, manual thinning was performed, leaving only the most vigorous plant in each hole.

To avoid seed loss with the dehiscence of some fruits, the racemes were covered using TNT bags, and harvested when $70 \%$ of fruits were dried. In order to complete fruit drying, the racemes were placed in a well-ventilated spot under cover. Seeds that were not removed from the fruits by dehiscence were manually removed with pruning shears.

Vegetative cycle was calculated by determining the difference between the date of germination and the date of flowering The first, third, and fourth racemes of each plant were used to evaluate the number and weight of seeds per plant,. A precision digital scale was used to determine the weight of seeds per plant.

Seed oil content was determined by the low field nuclear magnetic resonance (NMR) system, MQA Oxford 7005 (Oxford Instruments, Abingdon/ Oxfordshire, England), using an electromagnet of 0.47T.

Genetic parameters were estimated based on mixed models of the individual REML/BLUP type using the software $\mathrm{R}$ following the model: $\mathrm{y}=\mathrm{Xr}+\mathrm{Zg}+\mathrm{Wb}+\mathrm{e}$, where $\mathrm{y}$ is the vector of the data, $\mathrm{r}$ is the vector of the effects of repetition (assumed as fixed) summed to the general average, $g$ is the vector of genotype effects (assumed as random), b is the vector of block effects (assumed as random), and e is the vector of errors or residuals (assumed as random). Uppercase letters represent the incidence matrixes for these effects. The mixed models were analyzed by the software R (R DEVELOPMENT CORE TEAM, 2011) using the lmer function of the lme4 package (BATES et al., 2015). 
The data were submitted to analysis of variance, Pearson's linear correlation analysis, and the average values were grouped by the Scott-Knott test at the 5\% level in the software R.

Variance components were estimated using the formulas provided by REZENDE \& DUARTE (2007).

\section{RESULTS AND DISCUSSION}

Results of the genetic parameters are shown in table 1 . The values obtained for the coefficient of genotype variation varied from 2.90 to 14.66. According to RESENDE (2002), the coefficient of genotype variation, as a percentage of the general average, represent the amount of genetic variation that exists. However, these variations may be a consequence of several factors, such as the methods used to estimate the parameters, species studied, and environmental conditions.

Using the coefficient of genotypic variation $(\mathrm{CVg})$, it is possible to compare the genetic variability of the different characteristics analyzed (COSTA et al., 2006; RIBEIRO et al., 2009). The highest estimates for coefficient of genotypic variation were presented by WSP $(14.66 \%)$ and NSP $(12.33 \%)$; these values can be considered of moderate magnitude and indicated that among all the characters studied, these showed greater variability, allowing the achievement of gain by selection.

Coefficient of genotypic variation for oil content in the seed was 2.90 , demonstrating low variability for this character. This can be explained by the strong selection pressure, since only $21 \%$ of the original population possessed oil content higher than $50 \%$. The very close values, with a lower coefficient of genotypic variation, obtained for vegetative cycle and plant height (6.45 and 6.53) may indicate that these characters are highly correlated; therefore, selecting for one character will indirectly select for the other.

Estimates of coefficients of experimental variation $(\mathrm{CVe})$ ranged from 1.22 , for oil content in the seed, to 40.75 , for number of seeds. Therefore, there was good precision in obtaining and analyzing the data, considering the number of repetitions used.

The $\mathrm{CVg} / \mathrm{CVe}$ ratio determined the coefficient of relative variation $(\mathrm{CVr})$. This parameter allowed inferences to be made about the possibilities of achieving improvement in the evaluated population. Exception for OCS (2.37), all characters presented values below 1 , VEGC (0.55), WSP (0.45),

Table 1 - Estimation of genetic parameters obtained via restricted maximum likelihood and best linear unbiased predictor (REML/BLUP) in castor bean plant lineages in the Recôncavo da Bahia, UFRB, Cruz das Almas - BA, 2011.

\begin{tabular}{|c|c|c|c|c|c|}
\hline Genetic Parameters & VEGC & PHE & NSP & WSP & OCS \\
\hline Genotypic variance & 24.34 & 0.01 & 67.48 & 43.11 & 2.42 \\
\hline Environmental variance between blocks & 0.34 & 0.01 & 52.52 & 37.63 & 0.33 \\
\hline Residual variance & 78.05 & 0.13 & 703.55 & 204.60 & 0.43 \\
\hline Individual phenotypic variation & 102.73 & 0.17 & 823.56 & 285.34 & 3.19 \\
\hline Broad-sense heritability & 0.23 & 0.09 & 0.08 & 0.15 & 0.75 \\
\hline Selection accuracy & 0.74 & 0.56 & 0.52 & 0.67 & 0.97 \\
\hline Coefficient of genotypic variation $/ \%$ & 6.45 & 6.53 & 12.33 & 14.66 & 2.90 \\
\hline Coefficient of residual variation $/ \%$ & 11.55 & 19.15 & 40.75 & 31.94 & 1.22 \\
\hline Coefficient of experimental accuracy $/ \%$ & 5.77 & 9.57 & 20.37 & 15.97 & 0.61 \\
\hline Coefficient of relative variation & 0.55 & 0.34 & 0.30 & 0.45 & 2.37 \\
\hline Variance of the prediction error & 10.83 & 0.01 & 48.77 & 23.39 & 0.01 \\
\hline Standard deviation of genotypic value & 3.29 & 0.10 & 6.98 & 4.83 & 0.10 \\
\hline Minimum & 63 & 1.25 & 33 & 24.00 & 50.33 \\
\hline Maximum & 98 & 2.96 & 105 & 69.00 & 57.66 \\
\hline Average & 76 & 1.90 & 65 & 44.77 & 53.63 \\
\hline
\end{tabular}

VEGC - flowering of primary raceme; PHE - plant height; NSP - number of seeds per plant; WSP - weight of seeds per plant; OCS - oil content in the seed. 
PHE (0.34), and NSP (0.30). VENCOVSKY (1987) suggested that the closer to 1 the $\mathrm{CVg} / \mathrm{CVe}$ ratio, the better the prospects for character improvement. RIBEIRO et al. (2009) stated that the higher the CVr, the greater the chance of selecting genotypes with superior performance.

Coefficient of heritability expresses the amount of genetic variation in relation to the total phenotypic variation (FALCONER, 1987; VENCOVSKY, 1987). Broad-sense heritability of individual plots varied widely, with a higher value $(0.75)$ for seed oil content and a lower value for number of seeds (0.08). PATEL \& PATEL (2014) evaluated the oil content in a hybrid population of castor oil plants and obtained a broad-sense heritability value of 0.53 , a value below that obtained in the present study.

Low heritability observed for seed number indicates that selection for this character should be performed with caution, since the environment strongly influences phenotypic expression. In addition, it is not convenient to carry out the selection in early generations, with the need of advancement in the generations, followed by self-fecundation to obtain greater genetic gain.

Vegetative cycle presented a value of 0.23 for broad-sense heritability. This value is considered low compared to the results obtained by PASSOS et al. (2010). Those authors evaluated the vegetative cycle for crosses that originated the population under study, and reported the following values: 0.64 ('BRS 149 Northeast' $\times$ 'EBDA'); 0.38 ('BRS 149 Nordestina' $\times$ 'Sipeal 28'), 0.86 ('BRS 149 Nordestina' $\times$ 'Mirante 10') and 0.65 ('BRS 188 Paraguaçu' $\times$ 'EBDA MPA 17'). Similarly, OLIVEIRA (2011) reported a value of 0.66 in a segregating $\mathrm{F} 3$ population of castor bean plants.

Accuracy is associated with precision in selection, and is the main element of genetic progress that can be altered to maximize the genetic gain. Accuracy is obtained by the correlation between the genotypic value of the genetic treatment and that estimated or predicted from available information from the experiments (COSTA et al., 2005). Values obtained for this parameter can vary from 0 to 1 and can be classified as: very high ( $\breve{\mathrm{r} g g} \geq 0.90)$, high $(0.70 \leq \check{\mathrm{r}} \mathrm{gg}<0.90)$, moderate $(0.50 \leq \breve{\mathrm{r}} \mathrm{gg}<0.70)$, and low $(\check{\mathrm{r} g}<<0.50)$ (RESENDE, 2002; RESENDE \& DUARTE, 2007).

Results obtained for accuracy varied from 0.52 for the number of seeds per plant to 0.97 for oil content, and were classified as: moderate for PHE $(\check{\mathrm{r} g g}=0.56)$, NSP $(\check{\mathrm{r} g g}=0.52)$ and WSP $(\check{\mathrm{r} g g}=0.67)$,

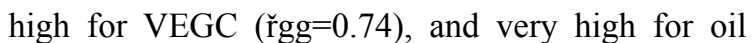
content ( $\breve{\text { rggg }}=0.97$ ). For REZENDE (2002), accuracy values exceeding 0.70 are sufficient to ensure good precision on the genetic value, which can be observed for the vegetative cycle and oil content in the present study. However, an experiment with at least seven replicates is required to obtain experiments with accuracy above 0.90 (RESENDE \& DUARTE 2007).

The experiment included four replicates; therefore, the number of replicates may have contributed to the low proportion of ideal selective accuracy in most characters. Thus, it is necessary to evaluate experimental techniques that have not previously been used for castor bean plants in order to improve test efficiency. In the present study, the estimates of genetic parameters obtained for the advanced population will serve as a basis for selection of elite lineages of castor bean plant, in order to obtain genetic gains in crop improvement.

Table 2 shows the correlation between the characters evaluated in castor bean plant genotypes in the 2 years of cultivation. Except for the correlations between PHE $\times$ NSP and PHE $\times$ OCS, there was a significant correlation at the $5 \%$ level among all evaluated characters indicating a high degree of association, but with a low proportion.

Knowledge on the magnitude and direction of genotype correlations between characters is extremely important for the breeder to formulate simultaneous selection strategies in multiple characters. This is advantageous, especially when a character of high economic value has low heritability, or is difficult to evaluate compared to another

Table 2 - Genetic correlations among five characters evaluated in castor bean plant lineages in the Recôncavo da Bahia (UFRB), Cruz das Almas - BA, 2011.

\begin{tabular}{lccccc}
\hline & VEGC & PHE & NSP & WSP & OCS \\
VEGC & & & & & \\
PHE & $0.08^{*}$ & & & \\
NSP & $-0.16^{*}$ & $0.02^{\mathrm{ns}}$ & & \\
WSP & $-0.15^{*}$ & $0.08^{*}$ & $0.76^{*}$ & \\
OCS & $-0.17^{*}$ & $-0.02^{\mathrm{ns}}$ & $0.22^{*}$ & $0.15^{*}$ \\
\hline
\end{tabular}

Significant at the $5 \%$ level $(*)$ and not significant at the $5 \%$ level (NS), by the t-test. Vegetative cycle in days (VEGC); plant height in $\mathrm{m}$ (PHE); number of seeds per plant (NSP); weight of seeds per plant in $\mathrm{g}$ (WSP); percentage of oil content in the seeds (OCS). 
associated character (RODRIGUES et al., 2010; RODRÍGUEZ et al., 1998).

There were significant correlations between vegetative cycle and all characters, which were positive with the PHE and negative with the other characters. Similar results were obtained in studies by OLIVEIRA (2011). These correlations indicated that reducing the vegetative cycle yields genotypes with lower height, higher number and weight of seeds per plant, and higher seed oil content. A positive correlation was also observed between vegetative cycle and plant height in a study by ARIF et al. (2017) who evaluated 63 castor bean accessions in Pakistan.

For plant height there was a significant and positive correlation between the vegetative cycle and weight of seeds. These results indicated that, it is possible to obtain productive lineages in the evaluated population, which are early and of low size, attending to the main objective of the genetic improvement program of the crop.

For seed oil content, there was no significant correlation for plant height only. Moreover, the nonsignificance of the correlation between two characters indicates that they can be manipulated independently during the selection process; thus, when selecting for one of the characters, the average of the other will not be changed (CRUZ \& CARNEIRO, 2003).

\section{CONCLUSION}

Genetic progress can be made by selecting the character seed oil content due to its considerable heritability and high accuracy in the studied population.

The characteristic of seed number and weight per plant presented greater variability, which allows us to anticipate considerable genetic gains through selection, maintaining the distinction between elite lineages.

Positive correlations between the vegetative cycle and plant height, associated with negative correlations for number and weight of seeds, and oil content, allow significant gains in crop productivity.

\section{ACKNOWLEDGEMENTS}

The authors would like to thank Petrobras and the National Petroleum Agency, the Universidade Federal do Recôncavo da Bahia, the Coordination for the Improvement of Higher Education Personnel, and the Advanced Laboratory of Chemical Technology of Embrapa Cotton.

\section{DECLARATION OF CONFLICT OF INTEREST}

The authors declare no conflict of interest. The founding sponsors had no role in the design of the study; in the collection, analyses, or interpretation of data; in the writing of the manuscript, and in the decision to publish the results.

\section{AUTHORS' CONTRIBUTIONS}

The authors contributed equally to the manuscript.

\section{REFERENCES}

ARIF, M. et al. Estimating spatial population structure through quantification of oil content and phenotypic diversity in pakistani castor bean (Ricinus communis L.) germplasm.Science Technology and Development, v. 34, n. 3, p. 147-154, 2017. <doi: 10.3923/ std.2015.147.154>.

BAJAY, M. M. et al. Development and characterization of microsatellite markers for castor (Ricinus communis L.), an important oleaginous species for biodiesel production. Conservation Genetics Resources. v. 1, n. 1, p. 237-239, 2009. <doi: 10.1007/s12686-009-9058-z>.

BATES, D. et al. Ime4: Linear Mixed-Effects Models Using Eigen and S4. R package version 1, p.1-10, 2015. Available from : $<$ http:// CRAN.R-project.org/package $=1 \mathrm{me} 4>$. Accessed: Oct. 2018.

COSTA, M. da N. et al. Divergência genética entre acessos e cultivares de mamoneira por meio de estatística multivariada. Pesquisa Agropecuária Brasileira, v. 41, n. 11, p. 1617-1622, 2006. <http://dx.doi.org/10.1590/S0100204X2006001100007>.

COSTA, R. B. et al. Variabilidade genética e estimativas de herdabilidade para o caráter germinação em matrizes de Hevea brasiliensis. Floresta e Ambiente, v. 12, n. 1, p. 74-75, 2005. Available from: <http://s3.amazonaws.com/host-article-assets/ floram/588e220ee 710 ab87018b4623/fulltext.pdf>. Accessed: Jul. 2018.

CRUZ, C. D.; CARNEIRO, P. C. S. Modelos biométricos aplicados ao melhoramento genético. Viçosa: UFV, 2003. 585p.

CRUZ, C. D.; et al. Modelos biométricos aplicados ao melhoramento genético. Viçosa: UFV, 1997. 390 p.

DA SILVA, J. A. G. et al. Caracterização e herdabilidade em caracteres morfológicos e fisiológicos da mamona. Revista Brasileira de Agrociência, v.17, n. 3-4, p. 348-358, 2011. <HTTP://DX.DOI.ORG/10.18539/CAST.V17I3.2068>.

DAPKE, J. S. et al. Genetic variability in castor (Ricinus communis L.). European Journal of Biotechnology and Bioscience, v. 4, n. 4, p. 39-40, 2016. < doi.org/10.22271/bioscience>.

FALASCA, S. L. et al. Developing an agro-climatic zoning model to determine potential production areas for castor bean (Ricinus communis L.). Industrial Crops and Products, v. 40, n. 1, p. 185191, 2012. <doi:10.1016/j.indcrop.2012.02.044>. 
JEONG, G. T.; PARK, D. H. Optimization of biodiesel production from castor oilcastor (Ricinus communis L.) using response surface methodology. Applied Biochemistry Biotechnology, v. 156, 431-441, 2009. <doi: 10.1007/s12010-008-8468-9>.

MARTINEZ, D. T. et al. Procedimentos de predição e efeitos da heterogeneidade de variância residual dentro de tratamentos genéticos. Pesquisa Florestal Brasileira, v. 31, n. 67, p. 193-202, 2011. <doi: 10.4336/2011.pfb.31.67.193>.

OLIVEIRA JUNIOR, I. de; ZANOTTO, M. D. Eficiência da seleção recorrente para redução de estatura de plantas em mamoneira (Ricinus communis L.). Ciência Agrotecnologia, v. 32, n. 4, p. 1107-1112, 2008. <http://dx.doi.org/10.1590/S1413$70542008000400011>$.

OLIVEIRA, R. S. de. Avaliação de população segregante (F3) de mamoneira em condições do Recôncavo Baiano. 2011. 40 f. Dissertação (Mestrado) - Universidade Federal do Recôncavo da Bahia, Cruz das Almas, 2011. Available from: <https:// www.ufrb.edu.br/ pgcienciasagrarias/teste/category/26-ano2011?download=301>. Accessed: Oct. 2018 .

PATEL, J.K.; PATEL, P.C. Genetic variability, heritability and genetic advance for yield and yield components in castor (Ricinus communis L.). Genotypes International Journal of Plant Science, v. 9, n. 2, p. 385-388, 2014. Available from: <http:// www.researchjournal. co.in/upload/assignments/9_385-388.pdf>. Accessed: Sept.2018.

PASSOS, A. R. et al. Parâmetros genéticos de caracteres agronômicos em genótipos de mamoneira. Pesquisa Agropecuária Brasileira, v. 45, n. 7,p. 709-714, 2010.<http://dx.doi.org/10.1590/ S0100-204X2010000700011>.

$R$ DEVELOPMENT CORE TEAM R. A language and environment for statistical computing. $R$ Foundation for Statistical Computing, Vienna, Austria, 2011. Available from: $<$ http://www.R-project.org/>. Accessed Jul. 2017.

RESENDE, M. D. V. Genética biométrica e estatística no melhoramento de plantas perenes. Brasília: Embrapa Informação Tecnológica, 2002. 975 p. Available from: <http://livraria.sct. embrapa.br/liv_resumos/pdf/00070180.pdf>. Accessed Aug. 2018.

RESENDE, M. D. V.; DUARTE, J. B. Precisão e controle de qualidade em experimentos de avaliação de cultivares. Pesquisa
Agropecuária Tropical, v. 37, n. 3, p. 182-194, 2007. Available from: $\quad<$ http://www.redalyc.org/articulo.oa?id=253021631009>. Accessed: Sept. 2018.

RIBEIRO, E. H. et al. Estimativas de parâmetros genéticos e seleção de linhagens endogâmicas recombinantes de feijoeiro comum (Phaseolus vulgaris L.). Revista Ceres, v. 56, n. 5, p. 580590, 2009. Available from: <http://www.ceres.ufv.br/ojs/ index. php/ceres/article/view/3470/1368>. Accessed: Aug. 2018.

ROCHA, M. M. et al. Estimativas de parâmetros genéticos em genótipos de feijão caupi de tegumento branco. Revista Científica Rural, v. 8, n. 1, p. 135-141, 2003. Available from: <https:// www.alice.cnptia.embrapa.br/alice/bitstream/doc/66139/1/ REVCIENRURAL80001.pdf $>$. Accessed: Sept.2018.

RODRÍGUEZ, R. E. S. et al. Estimativas de parâmetros genéticos e de respostas à seleção na população de arroz irrigado CNA 1. Pesquisa Agropecuária Brasileira, v.33, n.5, p. 685-691. 1998. Available from: <http://ainfo.cnptia.embrapa.br/digital/ bitstream/item/44793/1/ESTIMATIVAS-DE-PARAMETROSGENETICOS-E-DE-RESPOSTAS-A-SELECAO.pdf $>$. Accessed: Jul. 2018.

RODRIGUES, H. C. de A. et al. Correlações genotípicas, fenotípicas e ambientais entre caracteres de mamoneira. Ciência e Agrotecnologia. v. 34, n. 6, p. 1390-1395. 2010. <http://dx.doi. org/10.1590/S1413-70542010000600005>

SALIHU, B. Z. et al. Estimation of heritability and predicted genotype mean for seed yield of castor (Ricinus communis L.) Using best linear unbiased prediction (Blup). Journal of Plant Development. V. 24, p51-65, 2017. Available from: <https:// www.researchgate.net/publication/322011297> Accessed: Aug. 2018.

SEVERINO, L. S. et al. Avaliação da produtividade e teor óleo de dez genótipos de mamoneira cultivados em altitude inferior a 300 metros. Revista Ciência Agronômica, v. 37, n. 2, p. 188-194, 2006. Available from: http://ccarevista.ufc.br/seer/index.php/ ccarevista/article/view/199/193. Accessed: Aug 2018.

SILVA, A. R. et al. Genetic divergence among castor bean lines and parental strains using ward's method based on morphoagronomic descriptors. Acta Scientiarum Agronomy. v. 39, n. 3, p. 307-313, 2017. <http://dx.doi.org/10.4025/actasciagron. v39i3.32504>. 